\title{
PRODUCTION, PURIFICATION AND CHARACTERIZATION OF L-ASPARAGINASE FROM STREPTOMYCES GULBARGENSIS
}

\author{
Amena S., Vishalakshi N., Prabhakar M., Dayanand A., Lingappa K.*
}

Department of Microbiology, Gulbarga University, Gulbarga-585106 Karnataka, India.

Submitted: August 28, 2008; Returned to authors for corrections: March 16, 2009; Approved: September 28, 2009.

\begin{abstract}
L-asparaginase is an anti-neoplastic agent used in the lymphoblastic leukaemia chemotherapy. In the present study a novel strain, Streptomyces gulbargensis was explored for the production of extra-cellular L-asparaginase using groundnut cake extract. The optimum $\mathrm{pH}$, temperature, inoculum size and agitation speed for enzyme production were $\mathrm{pH} 8.5,40^{\circ} \mathrm{C}, 1 \times 10^{8}$ spores $/ \mathrm{ml}$ and $200 \mathrm{rev} / \mathrm{min}$ respectively. Maltose $(0.5 \%)$ and L-asparagine $(0.5 \%)$ proved to be the best carbon and nitrogen sources respectively. The enzyme was purified 82.12 fold and the apparent molecular weight of the enzyme was found to be $85 \mathrm{kDa}$. The optima $\mathrm{pH}$ and temperature for the enzyme were 9.0 and $40^{\circ} \mathrm{C}$ respectively. The enzyme was more stable at the alkaline $\mathrm{pH}$ than at the acidic one and it retained $55 \%$ of the activity at $80^{\circ} \mathrm{C}$ for $60 \mathrm{~min}$.
\end{abstract}

Key words: L-asparaginase, Streptomyces gulbargensis, Groundnut cake extract, Optimization, Purification.

L-asparaginase (L-asparagine aminohydrolase EC 3.5.1.1), the enzyme which converts L-asparagine to L-aspartic acid and ammonia has been used as a chemotherapeutic agent. It has received increased attention in recent years for its anticarcinogenic potential (11). The clinical action of this enzyme is attributed to the reduction of L-asparagine, since tumor cells unable to synthesize this amino acid are selectively killed by Lasparagine deprivation. The enzyme is produced by a large number of micro organisms that include Enterobacter cloacae (15), Serratia marcescens (2) and Enterobacter aerogenes (13). The enzymes isolated from E.coli and Erwinia carotovora are now being used in the treatment of acute lymphoblastic leukaemia (4). However, due to the prolonged administration of L-asparaginase, the corresponding antibodies are produced in man, which causes an anaphylactic shock or neutralization of the drug effect. Therefore there is a continuing need to screen newer organisms in order to obtain strains capable of producing new and high yield of L-asparaginase. Among the actinomycetes several Streptomyces species such as $S$. karnatakensis, S. venezualae, S. longsporusflavus and a marine Streptomyces sp. PDK2 have been explored for L-asparaginase production (14). The enzyme is produced throughout the world by both submerged and solid-state cultures. Extra-cellular asparaginases are more advantageous than intracellular since they could be produced abundantly in the culture broth under normal conditions and could be purified economically. In this paper, we report the production of an extra-cellular Lasparaginase by a novel isolate, Streptomyces gulbargensis (3) under submerged culture using groundnut cake extract. Attempts were made to study the optimization of Lasparaginase production, its purification and characterization from S. gulbargensis. 
The strain S.gulbargensis was obtained from the Department of Microbiology, Gulbarga University, Gulbarga, India. The isolate was identified as a novel strain at Yunnan Institute of Microbiology, China (3). It was maintained on starch casein agar slants ( $\mathrm{pH} 7.2)$ containing $\left(\mathrm{gL}^{-1}\right)$ Starch 10 , $\mathrm{K}_{2} \mathrm{HPO}_{4}$ 2.0, $\mathrm{KNO}_{3}$ 2.0, $\mathrm{NaCl} 2.0$, Casein $0.3, \mathrm{MgSO}_{4} .7 \mathrm{H}_{2} \mathrm{O}$ $0.05, \mathrm{CaCO}_{3}$ 0.02, $\mathrm{FeSO}_{4} .7 \mathrm{H}_{2} \mathrm{O} \quad 0.01$ and agar 20 at a temperature of $4^{\circ} \mathrm{C}$. Regular sub culturing of the isolate was performed at an interval of every 4 weeks.

\section{Inoculum preparation and Production of L-asparaginase}

Spore suspension was prepared from 5 day old culture grown on starch casein agar slant by adding $10 \mathrm{ml}$ of sterile distilled water containing $0.01 \%$ of Tween 80 and suspending the spores with a sterile loop (9). One $\mathrm{ml}$ of this spore suspension was used as an inoculum for production studies. Production of L-asparaginase was carried out in groundnut cake extract. The groundnut cake was obtained from the local market in Gulbarga city. The extract was prepared using ten grams of the powdered substrate dissolved in $100 \mathrm{ml}$ of distilled water, taken in $250 \mathrm{ml}$ Erlenmeyer flask. The contents of the flask were heated for about ten minutes, cooled to room temperature and then filtered using Whatman filter paper No.1. The extract thus obtained was used for bioprocess studies. The parameters studied for submerged culture were initial $\mathrm{pH}$ (6.5$9.0)$ of the medium, incubation temperature $\left(25-55^{\circ} \mathrm{C}\right)$, inoculum size $\left(1 \times 10^{5}-1 \times 10^{9}\right.$ spores $\left./ \mathrm{ml}\right)$ and agitation speed (140-200 rev/min). Once a given parameter was optimized, it was kept constant at that level while varying the other parameters individually. The effect of addition of various carbon and nitrogen sources on L-asparaginase production was determined in groundnut cake extract. The carbon sources were studied at a concentration of $0.5 \%$. The effect of different concentrations of nitrogen sources was studied by adding a nitrogen source to the extract supplemented with $0.5 \%$ maltose. The bioprocess was carried out in $250 \mathrm{ml}$ Erlenmeyer flask containing the optimized medium, kept in a shaker incubator (Remi Orbital Shaker Incubator). Samples were withdrawn at regular intervals of $24 \mathrm{~h}$ and assayed for L-asparaginase activity. All the experiments were performed independently in triplicates and the results given here are the mean of three values.

\section{Assay of L-asparaginase}

To determine the enzyme activity, $5 \mathrm{ml}$ of the culture broth was withdrawn aseptically from the flasks at an interval of every $24 \mathrm{~h}$. The broth was filtered using Whatman filter paper No.1 and then centrifuged (Sigma 3K30) at 9,000 g for $8 \mathrm{~min}$ (5). The supernatant thus obtained was used as crude extract for L-asparaginase assay. Assay of enzyme was carried out as per Imada et al. (7). The enzyme activity was expressed in IU. One IU of L-asparaginase is the amount of enzyme which liberates $1 \mu$ mole of ammonia per $\mathrm{ml}$ per $\min (\mu \mathrm{mole} / \mathrm{ml} / \mathrm{min})$.

\section{Purification of L-asparaginase}

The purification was carried out using crude enzyme extract (6). The enzyme was purified by the following steps at $0-4^{\circ} \mathrm{C}$, unless otherwise mentioned.

Finely powdered ammonium sulfate was added to the crude extract. The L-asparaginase activity was associated with the fraction precipitated at $40-60 \%$ saturation. The precipitate was collected by centrifugation at $9,000 \mathrm{~g}$ for $15 \mathrm{~min}$, dissolved in 50mM Tris- $\mathrm{HCl}$ buffer $\mathrm{pH} 8.6$ and dialyzed against the same buffer. The dialyzed fraction was applied to a Sephacryl S-200 column $(1 \mathrm{~cm} \times 50 \mathrm{~cm})$ that was pre-equilibrated with Tris- $\mathrm{HCl}$ buffer $\mathrm{pH}$ 8.6. The protein elution was done with the same buffer at a flow rate of $5 \mathrm{ml} / 30 \mathrm{~min}$. The active fractions were pooled, dialyzed and concentrated. The concentrated enzyme solution was applied to the column of CM Sephadex C-50 that was pre-equilibrated with $50 \mathrm{mM}$ Tris- $\mathrm{HCl}$ buffer $\mathrm{pH}$ 8.6. It was eluted with $\mathrm{NaCl}$ gradient $(0.1-0.5 \mathrm{M})$ and $0.1 \mathrm{M}$ borate buffer $\mathrm{pH}$ 7.0. The active fractions were collected, dialyzed and concentrated. The L-asparaginase was assayed by the direct Nesslerization method as described earlier. Protein estimation was done with Folin-Phenol reagent using BSA as a standard (10). SDS-PAGE was performed according to the method of Laemmli (8), with a separating acrylamide gel of $10 \%$ and stacking gel $5 \%$ containing $0.1 \%$ SDS. The gel was stained 
with coomassie brilliant blue R-250 and destained with a solution of methanol, acetic acid and water in the ratio of $4: 1: 5$. The following standard proteins were used for molecular weight determination $97.4 \mathrm{kDa}$ (Phosphorylase b), $66 \mathrm{kDa}$ (Bovine serum albumin), $43 \mathrm{kDa}$ (Ovalbumin), $29 \mathrm{kDa}$ (Carbonic anhydrase), $18.4 \mathrm{kDa}$ (Lactoglobulin) and $14.3 \mathrm{kDa}$ (Lysozyme).

\section{pH and Temperature Studies}

The activity of L-asparaginase was evaluated at different $\mathrm{pH}$ values and temperature. Partially purified enzyme was incubated with $0.04 \mathrm{M}$ L-asparagine and $0.05 \mathrm{M}$ buffers of $\mathrm{pH}$ 4-10, under assay conditions and the amount of ammonia liberated was determined. For stability check, the enzyme was incubated at different $\mathrm{pH}$ in the absence of substrate. Buffers used were potassium phosphate $(\mathrm{pH} 4.0-7.0)$, Tris- $\mathrm{HCl}(\mathrm{pH}$ 8.0-9.0) and glycine- $\mathrm{NaOH}(\mathrm{pH} 10)$. The pre-incubation was carried out for $60 \mathrm{~min}$ and then the residual activity was measured. The optimum temperature for the enzyme activity was determined by incubating the assay mixture at temperatures ranging from $10-100^{\circ} \mathrm{C}$. Thermostability studies were carried out by pre-incubating the enzyme at different temperatures for $60 \mathrm{~min}$.

The analysis of L-asparaginase production was carried out at every $24 \mathrm{~h}$ interval after inoculation with the maximum activity obtained at $120 \mathrm{~h}$ of incubation (Table 1). The yield of L-asparaginase increased with increase in initial $\mathrm{pH}$ of the medium up to 8.5 and thereafter it decreased. The maximum yield (9.8 IU) was obtained at $\mathrm{pH} 8.5$ and minimum (6.4 IU) at pH 6.5. Narayana et al. (14) have reported the optimum pH for L-asparaginase production by Streptomyces albidoflavus to be 7.5. Maximum yield of L-asparaginase (10.5 IU) was observed at a temperature of $40^{\circ} \mathrm{C}$, and the lowest (4.9 IU) at temperature $55^{\circ} \mathrm{C}$. Maximum production of L-asparaginase by $S$. albidoflavus was found to be at $35^{\circ} \mathrm{C}$ (14). An inoculum size of $1 \times 10^{8}$ spores $/ \mathrm{ml}$ showed the highest yield (11.0 IU) of Lasparaginase, while the lowest yield of enzyme was observed with an inoculum size of $1 \times 10^{5}$ spores $/ \mathrm{ml}$, producing $6.9 \mathrm{IU}$ of L-asparaginase. Optimization of inoculum size is necessary because too few spores lead to insufficient biomass, whereas too many spores lead to overproduction of biomass resulting in quick depletion of nutrients. The yield of enzyme increased with increase in agitation speed from 140-200 rev/min and decreased later. Maximum L-asparaginase production (12.1IU) was obtained at an agitation speed of 200rev/min and lowest yield (7.1 IU) at $140 \mathrm{rev} / \mathrm{min}$. Table 2 shows the effect of various carbon sources on L-asparaginase production by S.gulbargensis. Among all the carbon sources tested, maltose proved to be the best for L-asparaginase production yielding 19.5 IU of enzyme. Maximum L-asparaginase production using maltose as a sole carbon source has been reported in $S$. albidoflavus (14). However glucose, fructose, galactose, mannitol and arabinose proved to be inferior for $\mathrm{L}$ asparaginase synthesis. Glucose is known to lower the enzyme yield by acting as a repressor (13). Repression of Lasparaginase synthesis by glucose has been shown in bacteria such as Serratia marcescens (2) and E.coli (1). On the other hand, enhancement of L-asparaginase production by glucose was observed in Aeromonas sp. (16). The L-asparaginase production pattern using various nitrogen sources at different concentrations is presented in table 2 . Highest enzyme activity (25 IU) was recorded when groundnut cake extract was supplemented with $0.5 \%$ L-asparagine. Maximum Lasparaginase production using $0.1 \% \mathrm{~L}$-asparagine as the sole source of nitrogen has been observed in Enterobacter cloacae (15) and Aeromonas sp. (16). On the contrary, Narayana et al. (14) reported yeast extract (2\%) as the best nitrogen source for L-asparaginase production by $S$. albidoflavus.

The purification of L-asparaginase was carried out by 4 steps as shown in table 3, with a final yield of $32 \%$ and a purification fold of 82.12. L-asparaginase from S. albidoflavus has been purified in CM Sephadex C-50 column up to 99.3 fold with $40 \%$ recovery (14). Dhevagi and Poorani (4) reported 85 fold purification of L-asparaginase from Streptomyces sp.PDK2 by a final Sephadex G-200 gel filtration. SDS-PAGE analysis of the purified enzyme showed the apparent molecular weight of $S$. gulbargensis L-asparaginase to be $85 \mathrm{kDa}$. Purified L-asparaginase from Streptomyces sp.PDK2 (4) and S. 
albidoflavus (14) exhibited a molecular weight of $140 \mathrm{kDa}$ and $112 \mathrm{kDa}$ respectively.

The optimal $\mathrm{pH}$ determined for L-asparaginase activity of Streptomyces gulbargensis was 9.0. Similar observations have been reported for asparaginase from Pseudomonas stutzeri MB-405 (11). Dhevagi and Poorani (4) reported the maximum L-asparaginase activity of Streptomyces sp. PDK7 between $\mathrm{pH}$ 8.0 and 8.5. Regarding the $\mathrm{pH}$ stability, the enzyme retained more than $80 \%$ of the activity in the $\mathrm{pH}$ range of $7-10$. Our results are in good agreement with those of Manna et al. (11).The enzyme was found to be maximally active at $40^{\circ} \mathrm{C}$. This optimum L-asparaginase activity at $40^{\circ} \mathrm{C}$ is similar to that of Corynebacterium glutamicum, reported by Mesas et al. (12).
Regarding the thermal stability, at $80^{\circ} \mathrm{C}$, the enzyme retained $55 \%$ of the activity.

The present study revealed that, all the selected parameters examined, showed a considerable impact on L-asparaginase production by the novel isolate, S.gulbargensis in groundnut cake extract. To the best of our knowledge, this is the first report on the utilization of groundnut cake extract as a substrate/medium for the production of L-asparaginase by S.gulbargensis. Further, the high catalytic activity of the enzyme at physiological $\mathrm{pH}$ and temperature and its considerable stability over a wide range of $\mathrm{pH}$ and temperature makes it highly favorable to be exploited as a potent anticancer agent.

Table 1. Effect of various parameters on L-asparaginase production by S.gulbargensis

\section{Parameter}

\begin{tabular}{|c|c|c|c|c|c|c|}
\hline & $24 \mathrm{~h}$ & $48 \mathrm{~h}$ & $72 \mathrm{~h}$ & $96 \mathrm{~h}$ & $120 \mathrm{~h}$ & $144 \mathrm{~h}$ \\
\hline \multicolumn{7}{|l|}{$\mathrm{pH}$} \\
\hline 6.5 & 3.0 & 3.9 & 4.8 & 5.7 & 6.4 & 6.0 \\
\hline 7.0 & 3.2 & 4.2 & 5.5 & 6.6 & 7.3 & 6.8 \\
\hline 7.5 & 3.5 & 5.2 & 6.5 & 7.3 & 8.1 & 7.2 \\
\hline 8.0 & 3.9 & 6.6 & 7.8 & 8.2 & 8.9 & 8.2 \\
\hline 8.5 & 4.2 & 6.9 & 8.1 & 9.0 & 9.8 & 9.3 \\
\hline 9.0 & 3.8 & 6.3 & 7.4 & 8.1 & 8.7 & 8.1 \\
\hline \multicolumn{7}{|c|}{ Temperature $\left({ }^{0} \mathrm{C}\right)$} \\
\hline 25 & 2.9 & 4.0 & 4.8 & 5.5 & 6.9 & 5.7 \\
\hline 30 & 4.2 & 5.6 & 6.1 & 7.4 & 8.2 & 7.4 \\
\hline 35 & 5.3 & 6.2 & 7.7 & 8.3 & 9.7 & 8.8 \\
\hline 40 & 5.9 & 7.3 & 8.7 & 9.8 & 10.5 & 10.0 \\
\hline 45 & 4.3 & 5.7 & 6.3 & 7.4 & 8.5 & 8.0 \\
\hline 50 & 2.7 & 3.9 & 4.4 & 5.1 & 6.3 & 5.6 \\
\hline 55 & 1.8 & 2.1 & 3.0 & 3.9 & 4.9 & 4.0 \\
\hline \multicolumn{7}{|l|}{$\begin{array}{c}\text { Inoculum Size } \\
\text { (Spores } / \mathrm{ml})\end{array}$} \\
\hline $1 \times 10^{5}$ & 3.2 & 4.4 & 5.0 & 6.0 & 6.9 & 5.8 \\
\hline $1 \times 10^{6}$ & 4.5 & 5.8 & 6.4 & 7.6 & 8.4 & 7.5 \\
\hline $1 \times 10^{7}$ & 5.1 & 6.0 & 7.5 & 8.1 & 9.6 & 8.5 \\
\hline $1 \times 10^{8}$ & 6.4 & 7.9 & 9.1 & 10.2 & 11.0 & 10.4 \\
\hline $1 \times 10^{9}$ & 4.9 & 6.0 & 7.2 & 8.0 & 9.1 & 8.3 \\
\hline \multicolumn{7}{|c|}{$\begin{array}{l}\text { Agitation speed } \\
\text { (rev/min) }\end{array}$} \\
\hline 140 & 3.6 & 4.7 & 5.2 & 6.0 & 7.1 & 6.1 \\
\hline 160 & 4.7 & 5.7 & 6.8 & 7.7 & 8.5 & 7.6 \\
\hline 180 & 6.2 & 7.1 & 8.8 & 9.2 & 10.6 & 9.5 \\
\hline 200 & 6.8 & 7.9 & 9.7 & 11.0 & 12.1 & 11.3 \\
\hline 220 & 6.5 & 7.4 & 8.7 & 9.4 & 11.4 & 9.8 \\
\hline
\end{tabular}

\section{L-asparaginase activity (IU)}


Table 2. Effect of various carbon and nitrogen sources on L-asparaginase production by S.gulbargensis

\begin{tabular}{|c|c|c|c|c|c|}
\hline & \multicolumn{5}{|c|}{ L-asparaginase activity (IU) } \\
\hline & $0.25 \%$ & $0.5 \%$ & $0.75 \%$ & $1.0 \%$ & $1.25 \%$ \\
\hline \multicolumn{6}{|l|}{ Carbon Source } \\
\hline$\overline{\text { Glucose }}$ & - & 11.0 & - & - & - \\
\hline Fructose & - & 11.4 & - & - & - \\
\hline Sucrose & - & 17.8 & - & - & - \\
\hline Maltose & - & 19.5 & - & - & - \\
\hline Starch & - & 18.0 & - & - & - \\
\hline Galactose & - & 10.4 & - & - & - \\
\hline Arabinose & - & 10.9 & - & - & - \\
\hline Mannitol & - & 10.8 & - & - & - \\
\hline Xylose & - & 17.3 & - & - & - \\
\hline Lactose & - & 16.8 & - & - & - \\
\hline \multicolumn{6}{|l|}{ Nitrogen Source } \\
\hline$\overline{\text { Peptone }}$ & 17.2 & 18.1 & 17.3 & 16.2 & 15.7 \\
\hline Beef Extract & 20 & 22.4 & 19.8 & 18.1 & 14.3 \\
\hline Yeast Extract & 22.8 & 23.1 & 21.0 & 19.0 & 15.8 \\
\hline Tryptone & 14.7 & 16.3 & 16.9 & 14.8 & 13.6 \\
\hline Soyabean meal & 21.0 & 23.6 & 23.9 & 22.0 & 19.3 \\
\hline Cornsteep liquor & 22.8 & 24.0 & 23.3 & 20.9 & 18.6 \\
\hline Ammonium chloride & 15.1 & 16.8 & 15.0 & 14.3 & 11.3 \\
\hline Ammonium nitrate & 18.5 & 18.3 & 17.5 & 16.7 & 12.6 \\
\hline Ammonium sulfate & 23.2 & 21.8 & 19.8 & 17.3 & 16.4 \\
\hline L-asparagine & 23.1 & 25.0 & 24.6 & 21.2 & 19.1 \\
\hline
\end{tabular}

Table 3. Purification profile of L-asparaginase from S.gulbargensis

\begin{tabular}{lccccc}
\hline Step & $\begin{array}{c}\text { Total activity } \\
(\mathbf{I U})\end{array}$ & $\begin{array}{c}\text { Total protein } \\
(\mathbf{m g})\end{array}$ & $\begin{array}{c}\text { Specific } \\
\text { activity } \\
\text { (IU/mg) }\end{array}$ & $\begin{array}{c}\text { Purification } \\
\text { fold }\end{array}$ & Yield (\%) \\
\hline Crude Extract & 3200 & 128 & 25 & 0 & 100 \\
$\begin{array}{l}\text { Ammonium sulfate } \\
\text { precipitation }\end{array}$ & 1620 & 36 & 45 & 1.8 & 50.6 \\
$\begin{array}{l}\text { Sephacryl } \\
\text { S-200 gel filtration }\end{array}$ & 1210 & 1.8 & 672.2 & 26.88 & 37.8 \\
$\begin{array}{l}\text { CM Sephadex C- } \\
\text { 50 chromatography }\end{array}$ & 1026.5 & 0.5 & 2053 & 82.12 & 32 \\
\hline
\end{tabular}

\section{ACKNOWLEDGEMENTS}

The authors would like to thank Dr. Dastager S G for providing the strain S.gulbargensis.

\section{REFERENCES}

1. Barnas, W.R.; Dorn, G.L.; Vela, G.R. (1977). Effect of culture conditions on synthesis of L-asparaginase by E.coli A-1. Appl. Env. Microbiol. 33, 257-261.
2. Bernard, H.; Howard, A.J.; (1969). Production of tumor-inhibitory Lasparaginase by submerged growth of Serratia marcescenes. Appl. Microbiol. 18, 550-554.

3. Dastager, S.G.; Li, W.J.; Dayanand, A.; Sulochna, M.B.; Tang, S.K.; Tian, X.P.; Zhi, X.Y. (2007). Streptomyces gulbargensis sp. nov., isolated from soil in Karnataka, India. Antonie. Van. Leeuwenhoek. 91, 99-104.

4. Dhevagi, P.; Poorani, E.; (2006). Isolation and characterization of Lasparaginase from marine actinomycetes. Ind. J. Biotechnol. 5, 514-520. 
Amena, S. et al.

5. Ding, C.H.; Diang, Z.Q.; Li, X.T.; Li, L.Q.; Kusakabe, I. (2003). High activity xylanase production by Streptomyces olivaceoviridis E-86. World J. Microbiol.Biotechnol. 20, 7-10.

6. Distasio, J.A.; Salazar, A.M.; Nadji, M.; Durden, D.L.; (1982). Glutaminase-free asparaginase from Vibrio succinogenes: an antilymphoma enzyme lacking hepatotoxicity . Int. J. Cancer. 30, 343347.

7. Imada, A.; Igarasi, S.; Nakahama, K.; Isono, M. (1973). Asparaginase and glutaminase activities of microorganisms. J. Gen. Microbiol. 76, 85-89.

8. Laemmli, U.K. (1970). Cleavage of structural proteins during the assembly of the head of bacteriophage T4. Nature 227, 680-685.

9. Lingappa, K.; Vivek Babu, C.S. (2005). Production of lovastatin by solid state fermentation of carob (Ceratonia siliqua) pods using Aspergillus terreus KLVB28. Ind. J. Microbiol. 45, 283-286.

10. Lowry, O.H.; Rosenbrough, N.J.; Farr, A.L.; Randall, R.J. (1951). Protein measurement by Folin phenol reagent. J. Biol. Chem. 193, 266275.

11. Manna, S.; Sinha, A.; Sadhukan, R.; Chakrabarty, S.L. (1995).
Purification, characterization and antitumor activity of L-asparaginase isolated from Pseudomonas stutzeri MB-405. Curr. Microbiol. 30, 291298.

12. Mesas, J.M.; Gil, J.A.; Martin, J.F. (1990). Characterization and partial purification of L-asparaginase from Corynebacterium glutamicum. J. Gen. Microbiol. 136, 515-519.

13. Mukherjee, J.; Majumdar, S.; Scheper, T. (2000). Studies on nutritional and oxygen requirements for production of L-asparaginase by Enterobacter aerogenes. ApplMicrobiol. Biotechnol. 53, 180-184.

14. Narayana, K.J.P.; Kumar, K.G.; Vijayalakshmi, M. (2007). Lasparaginase production by Streptomyces albidoflavus. Ind J Microbiol. 48, 331-336.

15. Nawaz, M.S.; Zhang, D.; Khan, A.A.; Cerniglia, C.E. (1998). Isolation and characterization of Enterobacter cloacae capable of metabolizing asparagine. Appl.Microbiol. Biotechnol, 50, 568-572.

16. Pattnaik, S.; Kabi, R.; Janaki Ram, K.; Bhanot. K.K. (2000). Lasparaginase activity in Aeromonas sp. isolated from freshwater mussel. Ind. J. Exp. Biol. 38, 1143- 1146. 